\title{
RESPONSE OF NERICA RICE TO NITROGEN FERTILIZATION
}

\author{
R. Shultana ${ }^{1}$, M. A. A. Mamun $^{2}$, L. Naher ${ }^{1}$, M. K. A. Bhuiyan ${ }^{1}$ and A. J. Mridha ${ }^{1}$ \\ ${ }^{1}$ Agronomy Division, Bangladesh Rice Research Institute, Gazipur-1701 \\ ${ }^{2}$ Department of Agronomy, Bangabandhu Sheikh Mujibur Rahman Agricultural University, Gazipur-1706. \\ *Corresponding author: rakiba_83@yahoo.com
}

Key words: NERICA, nitrogen fertilizer, nitrogen use efficiency, yield

\begin{abstract}
An experiment was conducted during T. Aman season, 2014 at the Agronomy Research Field, Bangladesh Rice Research Institute, Gazipur to determine the optimum rate of nitrogen fertilizer for higher yield in nerica rice. The experiment comprised of three rice varieties viz. NERICA1, NERICA10 and BRRI dhan57; and five nitrogen levels viz. 0, 23, 46, 69 and 92 $\mathrm{kg} \mathrm{ha}^{-1}$. The rice var. BRRI dhan57 with 69 and $92 \mathrm{~kg} \mathrm{~N}^{-1}$ produced significantly identical with higher panicles $\mathrm{m}^{-2}$. But NERICA1 and NERICA10 produced higher number of panicles with 46 and $69 \mathrm{~kg} \mathrm{~N} \mathrm{ha}^{-1}$, respectively. However, BRRI dhan57 with $46 \mathrm{~kg} \mathrm{~N} \mathrm{ha}^{-1}$ produced highest grains panicle ${ }^{-1}$ but NERICA1 and NERICA10 produced higher number of grains panicle ${ }^{-1}$ with $23 \mathrm{~kg} \mathrm{~N} \mathrm{ha}^{-1}$. The highest percentage of sterility was recorded in NERICA10 with $69 \mathrm{~kg} \mathrm{~N} \mathrm{ha}^{-1}$. The regression analysis gave the optimum dose of nitrogen for NERICA1, NERICA10 and BRRI dhan57 which were $69.25,74.25$ and $85.75 \mathrm{~kg} \mathrm{~N} \mathrm{ha}^{-1}$, respectively.
\end{abstract}

\section{Introduction}

Rice (Oryza sativa L.) is the most extensively cultivated cereal crop in Bangladesh, which covers about $74 \%$ of the total cropped area (BBS, 2013). In respect of area and production of rice, Bangladesh ranks fourth following China, India and Indonesia (FAO, 2014). The area, production and yield of rice in the country are 11.42 million ha, 33.85 million tons and $2.96 \mathrm{t} \mathrm{ha}^{-1}$, respectively (BBS, 2013). Previous studies revealed that proper use of fertilizer can increase the yield and improve the quality of rice significantly (Awan et al., 2003; Ahmed et al., 2005; Oikeh et al., 2008). NERICA1 and NERICA10 is a new rice variety in Bangladesh which is short duration as well as drought tolerant. Development of proper fertilizer management strategy is one of the most important agronomic practices for its successful adoption in Bangladesh, especially in the drought prone areas. Among the agronomic practices, management of nitrogenous fertilizer plays the most important role for augmenting the rice yield.

Okeleye and Kehinde (2009) reported that application of $30 \mathrm{~kg} \mathrm{~N}$ in NERICA1 enhanced the number of tillers by $10 \%$ only at 21 days after transplanting (DAT) compared to zero-N. These results were also supported by Adigbo and Okeleye (2006) and Oikeh et al. (2008). Therefore, judicious dose of nitrogen fertilizer in Aman rice cv. NERICA1 and NERICA10 is necessary under Bangladesh condition. The present study was therefore conducted to determine the optimum rate of nitrogen fertilizer for getting higher yield in NERICA1 and NERICA10 varieties and compare with BRRIdhan 57.

\section{Materials and Method}

A field experiment was conducted during T. Aman season 2014 at the Agronomy Research Field, Bangladesh Rice Research Institute, Gazipur. The experiment was laid out in a Randomized Complete Block Design (RCBD) with three replications. Plot size was $4 \mathrm{~m} \times 3 \mathrm{~m}$. The experiment comprised of 
Shultana et al.

three rice varieties viz. NERICA1, NERICA10 and BRRI dhan57; and five nitrogen levels viz. 0, 23, 46, 69 and $92 \mathrm{~kg} \mathrm{ha}^{-1}$. Triple super phosphates, muriate of potash, gypsum and zinc sulphate were applied at 70-60-50-5 $\mathrm{kg} \mathrm{ha}^{-1}$. The whole dose of triple superphosphate, muriate of potash, gypsum, zinc sulphate and one third of nitrogen were applied at the time of sowing. The remaining doses of nitrogen were applied in two splits at tillering and panicle initiation. Data on yield and yield component were recorded at harvest and mean differences were depicted by multiple comparison test (Gomez and Gomez, 1984) using the statistical program MSTAT-C (Russell, 1986).

\section{Nitrogen use efficiency}

The efficiency of applied $\mathrm{N}$ was assessed using the following indices (Dobermann and Fairhurst, 2000).

\section{a. Agronomic efficiency (AE)}

Agronomic efficiency is the kg grain yield increase $\mathrm{kg}^{-1} \mathrm{~N}$ applied. Often used as nitrogen use efficiency (NUE).

$\mathrm{AE}_{\mathrm{N}}=\left(\mathrm{GY}_{+\mathrm{N}}-\mathrm{GY}_{0 \mathrm{~N}}\right) / \mathrm{FN}$

Where, $\mathrm{AE}_{\mathrm{N}}=$ Agronomic efficiency of $\mathrm{N} ; \mathrm{GY}_{+\mathrm{N}}=$ Grain yield due to addition of $\mathrm{FN} ; \mathrm{GY}_{0 \mathrm{~N}}=$ Grain yield without addition of $\mathrm{N} ; \mathrm{FN}=$ Amount of $\mathrm{N}$ applied $\left(\mathrm{kg} \mathrm{ha}^{-1}\right)$.

\section{b. Partial factor productivity (PFP)}

Partial factor productivity is the $\mathrm{kg}$ grain yield $\mathrm{kg}^{-1} \mathrm{~N}$ applied.

$\mathrm{PFP}_{\mathrm{N}}=\mathrm{GY}_{+\mathrm{N}} / \mathrm{FN}$

Where, $\mathrm{PFP}_{\mathrm{N}}=$ Partial factor productivity of $\mathrm{N} ; \mathrm{GY}_{+\mathrm{N}}=$ Grain yield due to addition of $\mathrm{FN} ; \mathrm{FN}=$ Amount of $\mathrm{N}$ applied $\left(\mathrm{kg} \mathrm{ha}^{-1}\right)$.

\section{Results and discussion}

\section{Yield components}

Among the yield components, panicles $\mathrm{m}^{-2}$ and sterility (\%) showed significant effect with different rates of fertilizer. BRRI dhan57 with nitrogen rate 69 and $92 \mathrm{~kg} \mathrm{ha}^{-1}$ produced panicles $\mathrm{m}^{-2}$ which was 202 and 203 respectively significantly higher and statistically similar. The highest number of panicles $\mathrm{m}^{-2}$ was found from NERICA1 and NERICA10 with 46 and $69 \mathrm{~kg} \mathrm{~N}^{-1}$, respectively. Nitrogen rates did not show any significant effect on grains panicle ${ }^{-1}$. However, BRRI dhan57 with $46 \mathrm{~kg} \mathrm{~N}$ produced highest grains panicle ${ }^{-1}(151)$. Besides NERICA1 and NERICA10 with $23 \mathrm{~kg}$ N/ha produced 68 and 79 grains/panicles, respectively. Increase in grain yield for application of $\mathrm{N}$ was mainly due to improvement in yield components i.e. number of effective tillers and grains panicle ${ }^{-1}$.

Thousand grain weight did not significantly influenced by $\mathrm{N}$ level in cultivated rice varieties. However, numerically maximum 1000-grain weight was recorded from NERICA1 with $69 \mathrm{~kg} \mathrm{~N} \mathrm{ha}^{-1}$. The highest sterility percent was recorded in NERICA10 with $69 \mathrm{~kg} \mathrm{~N} \mathrm{ha}^{-1}(43.40 \%)$. In contrary the lowest sterility percent (22.37\%) from BRRI dhan57 with $0 \mathrm{~kg} \mathrm{~N} \mathrm{ha}^{-1}$ (Table 1).

Table 1. Effect of nitrogen fertilizer on yield components of three rice varieties

\begin{tabular}{l|c|c|c|c}
\hline $\begin{array}{l}\text { N added } \\
\left(\mathrm{kg} \mathrm{ha}^{-1}\right)\end{array}$ & Panicles $\mathrm{m}^{-2}$ & Grains panicle $^{-1}$ & $\begin{array}{c}\text { 1000- grain weight } \\
(\mathrm{g})\end{array}$ & Sterility (\%) \\
\hline \multicolumn{7}{l}{} & \multicolumn{3}{c}{ NERICA1 } \\
\hline 0 & $121 \mathrm{~g}$ & 52 & 26.90 & $33.57 \mathrm{a}-\mathrm{e}$ \\
23 & $115 \mathrm{~h}$ & 68 & 27.23 & $27.90 \mathrm{cde}$ \\
46 & $146 \mathrm{~d}$ & 65 & 25.47 & $34.77 \mathrm{a}-\mathrm{d}$ \\
69 & $135 \mathrm{e}$ & 73 & 28.90 & $25.87 \mathrm{cde}$ \\
92 & $132 \mathrm{ef}$ & 75 & 28.63 & $29.47 \mathrm{cde}$ \\
\hline
\end{tabular}


Response of Nerica Rice to Nitrogen Fertilization

\begin{tabular}{|c|c|c|c|c|}
\hline \multicolumn{5}{|c|}{ NERICA10 } \\
\hline 0 & 131ef & 68 & 24.13 & 32.70 a-e \\
\hline 23 & $127 \mathrm{fg}$ & 79 & 25.13 & $30.93 \mathrm{~b}-\mathrm{e}$ \\
\hline 46 & $143 d$ & 77 & 22.83 & 28.87 cde \\
\hline 69 & $150 \mathrm{~d}$ & 76 & 24.90 & $43.40 \mathrm{a}$ \\
\hline 92 & $147 d$ & 74 & 25.26 & $42.10 \mathrm{ab}$ \\
\hline \multicolumn{5}{|c|}{ BRRI dhan57 } \\
\hline 0 & $176 \mathrm{~b}$ & 129 & 18.73 & $22.37 \mathrm{e}$ \\
\hline 23 & $167 \mathrm{c}$ & 133 & 18.47 & $24.43 \mathrm{de}$ \\
\hline 46 & $178 b$ & 151 & 18.57 & $24.30 \mathrm{de}$ \\
\hline 69 & $202 a$ & 144 & 17.83 & 27.80 cde \\
\hline 92 & $203 a$ & 141 & 18.33 & 28.77 cde \\
\hline $\mathrm{CV}(\%)$ & 2.52 & 17.68 & 6.42 & 19.87 \\
\hline
\end{tabular}

** and * indicates significant at 1 and $5 \%$ level, NS = not significant and similar letters within the column did not differ significantly by DMRT

\section{Grain yield}

The variety BRRI dhan 57 with $69 \mathrm{~kg} \mathrm{~N}^{-1}$ produced higher yield $\left(4.16 \mathrm{t} \mathrm{ha}^{-1}\right)$ which was $53.50 \%$ higher than control plot. Besides NERICA1 and NERICA10 did not show response with different levels of nitrogen. NERICA1 with $69 \mathrm{~kg} \mathrm{~N} \mathrm{ha}^{-1}$ produced $128.21 \%$ higher yield than $0 \mathrm{~kg} \mathrm{~N}$ treated plot which was statistically similar with $92 \mathrm{~kg} \mathrm{~N} \mathrm{ha}^{-1}$, produced $127.35 \%$ higher yield than control plot. Uddin et al. (2013) reported that NERICA1 produced the highest grain yield $\left(2.96 \mathrm{t} \mathrm{ha}^{-1}\right)$ with 80 $\mathrm{kg} \mathrm{N} \mathrm{ha}^{-1}$.

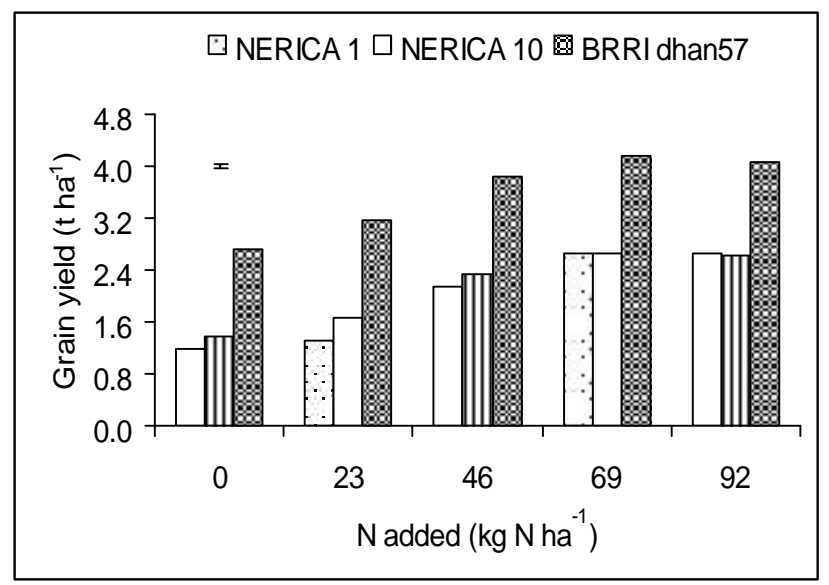

Fig. 1. Effect of different $\mathrm{N}$ doses on grain yield of NERICA rice.

Furthermore, NERICA10 with $69 \mathrm{~kg} \mathrm{~N} / \mathrm{ha}$ produced $127.35 \%$ higher yield than control plot which was statistically similar with $92 \mathrm{~kg} \mathrm{~N} / \mathrm{ha}$, produced $100 \%$ higher yield than control plot. It revealed that BRRI dhan57 responded higher with increased rate of nitrogen fertilizer but NERICA1 and NERICA10 have lower response with nitrogen fertilizer. Kisetu et al. (2013) stated from different reports that very low response of NERICA4 rice cultivar to various $\mathrm{N}$ levels in different parts of Tanzania.

\section{Straw yield}

BRRI dhan57 with $69 \mathrm{~kg} \mathrm{~N} h a^{-1}$ produced the highest straw yield $\left(4.20 \mathrm{t} \mathrm{ha}^{-1}\right)$ whereas NERICA1 and NERICA10 produced straw yield of 4.20 and $3.33 \mathrm{t} \mathrm{ha}^{-1}$ with $46 \mathrm{~kg} \mathrm{~N} \mathrm{ha}^{-1}$ (Fig. 2). Irshad et al. (2000) stated that $\mathrm{N}$ application increased straw yield over the absolute control. 


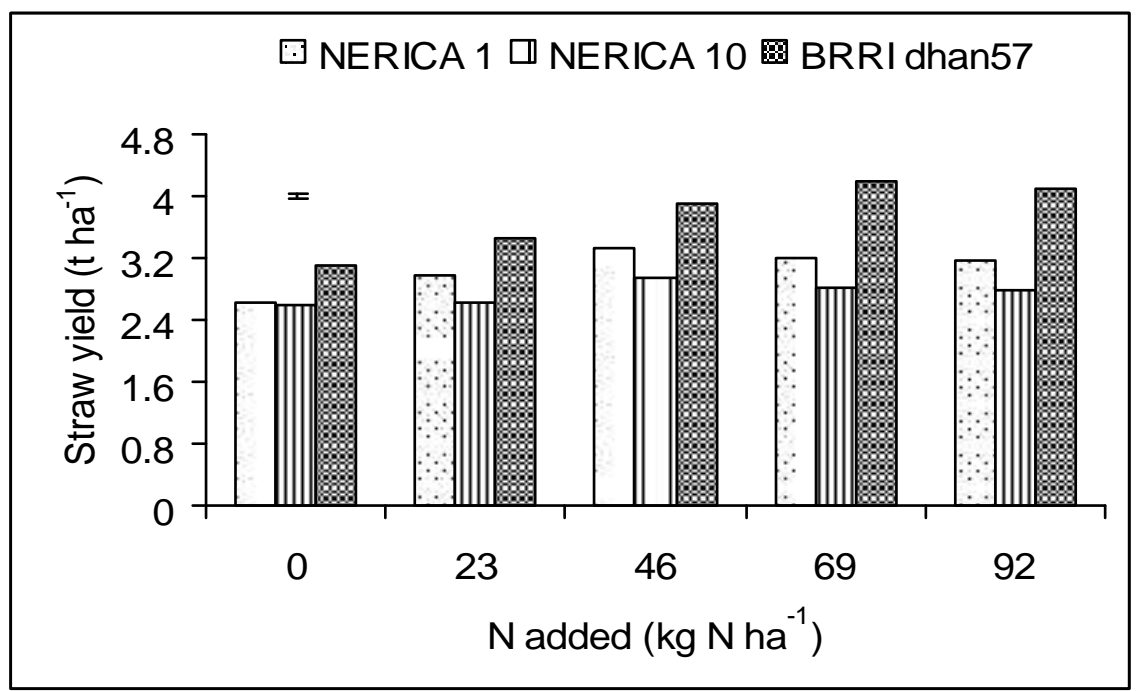

Fig. 2. Effect of different $\mathrm{N}$ doses on straw yield of NERICA rice

\section{Calculation of optimum nitrogen doses for nerica rice}

The regression line clearly indicated the relationship among three varieties with different rates of nitrogen fertilizer. Moreover, calculation for optimum nitrogen rates for three different rice varieties depicts that for getting higher yield in BRRI dhan57 it requires $85.75 \mathrm{~kg} \mathrm{~N} \mathrm{ha}^{-1}$. However, NERICA 1 could gave higher yield at $69.25 \mathrm{~kg} \mathrm{~N} \mathrm{ha}^{-1}$ and NERICA 10 with $74.25 \mathrm{~kg} \mathrm{~N}^{-1}$ but grain yield is much lower than BRRIdhan 57 (Fig. 3)

\section{Agronomic use efficiency and Partial factor productivity}

The rice var. BRRI dhan 57 with fertilizer rates $46 \mathrm{~kg} \mathrm{~N}^{-1}$ showed higher agronomic use efficiency (24.5). Besides, the lowest (14.6) was found in BRRI dhan57 with $92 \mathrm{~kg} \mathrm{~N} \mathrm{ha}^{-1}$. In case of NERICA1 variety the highest agronomic use efficiency (21.7) was found in $69 \mathrm{~kg} \mathrm{~N} \mathrm{ha}^{-1}$. However, NERICA10 showed higher agronomic use efficiency at $46 \mathrm{~kg} \mathrm{~N}^{-1}$ (21.3). On the other hand, the var. BRRI dhan57 with fertilizer rates $0 \mathrm{~kg} \mathrm{~N} \mathrm{ha}^{-1}$ showed higher partial factor productivity (137.6) among three varieties whereas NERICA1 and NERICA10 showed lowest with higher rates of nitrogen level (Table 2). 


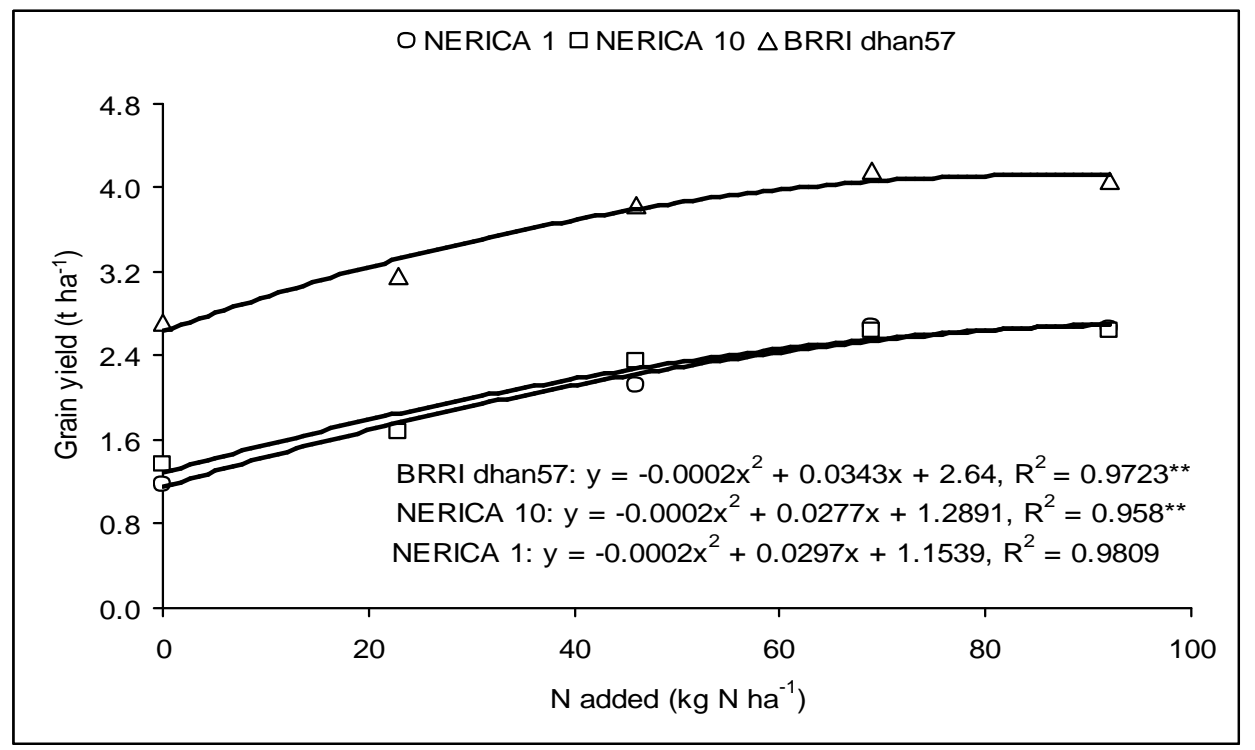

Fig. 3. Calculation of optimum nitrogen fertilizer dose for NERICA rice

Table 2. Agronomic use efficiency and Partial factor productivity of Nerica rice

\begin{tabular}{l|c|c|c|c|c|c}
\hline \multirow{2}{*}{$\begin{array}{l}\text { N applied } \\
\left(\mathrm{kg} \mathrm{ha}^{-1}\right)\end{array}$} & \multicolumn{2}{|c|}{$\begin{array}{c}\text { Agronomic use efficiency (AUE) } \\
\text { (kg grain per kg N applied) }\end{array}$} & \multicolumn{2}{c}{$\begin{array}{c}\text { Partial factor productivity (PFP) } \\
\text { (kg grain per kg N applied) }\end{array}$} \\
\cline { 2 - 7 } & NERICA1 & NERICA10 & BRRI dhan57 & NERICA 1 & NERICA 10 & $\begin{array}{c}\text { BRRI } \\
\text { dhan57 }\end{array}$ \\
\hline 23 & 6.5 & 13.0 & 20.0 & 57.3 & 72.5 & 137.6 \\
46 & 20.8 & 21.3 & 24.5 & 46.2 & 51.0 & 83.3 \\
69 & 21.7 & 18.5 & 21.0 & 38.6 & 38.3 & 60.2 \\
92 & 16.2 & 13.8 & 14.6 & 28.9 & 28.6 & 44.1 \\
\hline
\end{tabular}

\section{Conclusion}

It could be concluded that rice var. BRRIdhan 57 showed higher grain yield with $85 \mathrm{~N} \mathrm{Kg} / \mathrm{ha}$ whereas NERICA1 and NERICA10 with 69.25 and $74.25 \mathrm{~kg} \mathrm{~N}$ ha $^{-1}$ during T. Aman season but this two variety gave much lower grain yield than the former one.

\section{References}

Adigbo, S. O. and K. A. Okeleye. 2006. Green manuring and nitrogen fertilization effects on soil chemical properties, agronomic traits and grain yield of upland rice. Moor J. Agric. Res. 7(1): 18.Ahmed, M., M. M. Islam and S. K. Paul. 2005. Effect of nitrogen on yield and other plant characters of local T. aman Rice, Var. Jatai. J. Agric. Biol. Sci. 1: 158-161.

Awan, K. H., A. M. Ranjha, S. M. Mehdi, M. Sarfraz and G. Hassam. 2003. Response of rice line PB-95 to different NPK levels. J. Bio. Sci. 3: 157-166.

BBS (Bangladesh Bureau of Statistics). 2013. Monthly Statistical Bulletin of rice news on 8 December, 2011. Statistics Division, Ministry of Planning, Government People's Republic of Bangladesh, Dhaka. p. 65.

Gomez, K. A. and A. A. Gomez. 1984. Statistical Procedures for Agricultural Research. 2nd Ed., John Wiley and Sons, New York. pp. 202-215. 
Shultana et al.

Irshad, A., G. Abbas and A. Khaliq. 2000. Effect of different nitrogen application techniques on the yield and yield components of fine rice. Int. J. Agric. Biol. 2(3): 239-241.

Kisetu, E., J. Kasian and Z. S. Mtakimwa. 2013. Determination of urea-N levels application to NERICA4 cultivar of rice (Oryza sativa L.) grown on soils of Dakawa-Morogoro, Tanzania. A. Int. J. of Agric. Sci. 1(6): 73-80.

Oikeh, S., S. Diatta and T. Tsuboi. 2008. Soil Fertility and NERICA Rice Nutrition. In: Somado EA, Guei RG, Keya SO (Eds) NERICA: The New Rice for Africa Compendium. Africa Rice Centre, Cotonou, Benin, pp. 75-82.

Okeleye, K. A. and D. T. Kehinde. 2009. Influence of Legume/rice Sequence and Nitrogen on NERICA rice in Rainfed Upland and Lowland Ecologies of West Africa. The Proceedings of the International Plant Nutrition Colloquium XVI, Department of Plant Sciences, UC Davis. University of Agriculture, Abeokuta, Nigeria.

Russell, D. F. 1986. MSTAT-C computer based data analysis software).Crop and Soil Science Department, Michigan State University, USA.

Uddin, S., M. A. R. Sarkar and M. M. Rahma. 2013. Effect of nitrogen and potassium on yield of dry direct seeded rice cv. NERICA1 in aus season. Int. J. Agron. Plant Prod. 4(1): 69-75. 